\title{
Untreated and formaldehyde-treated urea as nitrogen sources for lactating dairy cows
}

\author{
JOUKO SETÄLÄ and LIISA SYRJÄLÄ-QVIST
}

Department of Animal Husbandry, Unive ty of Helsinki

\begin{abstract}
An experiment was performed with 22 Friesian cows, using a double reversal design with two treatments and one similar sequence for the two groups. The lengths of the standardization period, adaptation periods, test period and post-test period were $4,1,8$ and 4 weeks, respectively.

During the standardization and post-test periods the cows received pre-wilted grass silage ad libitum and a small amount of field-dried baled hay. In the test period hay was given ad libitum and the amount of grass silage was restricted. A concentrate mixture (barley, oats, minerals) was given daily to each cow at the rate of $0.3 \mathrm{~kg} / \mathrm{kg} 4 \%$ milk. During the standardization and post-test periods the mixture contained one per cent of untreated urea and during the test period $2.5 \%$ of untreated or treated urea. The urea had been treated with $1.5 \%$ formaldehyde on a weight basis.

The concentrate mixture was fed individually to each cow, but group feeding was used for the roughage.

Among the cows producing more than $15 \mathrm{~kg}$ of $4 \%$ milk a day, those receiving formaldehyde-treated urea had a significantly $(P<0.01)$ higher milk yield, and the fat content of their milk was significantly $(P<$ $0.05)$ lower than the group receiving untreated urea. Among the cows producing less than $15 \mathrm{~kg}$ of $4 \%$ milk/day, the group given treated urea had a significantly $(\mathrm{P}<0.05)$ higher milk fat content. No significant differences were found between the groups in the protein content of the milk.

Formaldehyde was found in five milk samples (total 55) taken from the formaldehyde-urea group during the test period. The formaldehyde content of these samples varied from 0.2 to $0.3 \mathrm{mg} / \mathrm{kg}$ milk.
\end{abstract}

\section{Introduction}

The effect of formaldehyde treatment on the utilization of urea has been tested in earlier experiments performed by SETÄLÄ and SYRJÄLÄ-QVIST (1982 $a, b, c)$. The degradation of urea to ammonia, microbial protein synthesis, and the digestibility and nitrogen utilization of the total ration were studied both in vitro and in vivo. The formaldehyde treatment giving the best results in these experiments was used in further studies. In the present experiment untreated urea and urea treated with $1.5 \%$ formaldehyde on a weight basis were tested as sources of nitrogen for lactating dairy cows. 


\section{Materials and methods}

The experiment was performed using a double reversal design with two treatments and one similar sequence for the two groups. The experiment started about seven weeks after calving. The periods and their lengths in the experimental design were as follows:

standardization period, adaptation period, test period, adaptation period, post-test period,
4 weeks

1 week

8 weeks

1 week

4 weeks

\section{Animals and their feeding}

The test animals were 22 Friesian cows, six of which were first calvers. The cows were already receiving $1 \%$ of untreated urea in their concentrates before calving. At the end of the standardization period they were divided into two groups which were similar to each other in respect of the milk yield during the standardization period, liveweight, days elapsed since calving and number of calvings.

Roughage was fed and consumption of roughage was calculated on a group basis. During the standardization and post-test periods the animals received pre-wilted, formic acid-formaldehyde-treated grass silage (Table 1) ad libitum. A restricted amount of hay was given during these periods.

In the test period field-dried, baled hay was given ad libitum and the amount of grass silage was restricted to $10 \mathrm{~kg} / \mathrm{cow} / \mathrm{day}$.

The concentrate mixture (Table 2) was fed individually, each cow receiving a daily ration of $0.3 \mathrm{~kg} / \mathrm{kg} 4 \%$ milk. In the test period untreated or formaldehyde-treated urea was given sufficient to cover about $25-30 \%$ of

Table 1. The average chemical composition and feeding value of the feeds.

\begin{tabular}{lccccc}
\hline & Concentrate $\left.{ }^{1}\right)$ & Grass silage $\left.{ }^{2}\right)$ & Hay & $\begin{array}{c}\text { Untreated } \\
\text { urea }\end{array}$ & $\begin{array}{c}\text { HCHO-treated } \\
\text { urea }\end{array}$ \\
\hline $\begin{array}{l}\text { Dry matter, \% } \\
\text { \% of dry matter }\end{array}$ & 87.0 & 22.7 & 85.7 & 99.7 & 99.3 \\
Ash & 3.2 & 6.2 & 7.8 & - & - \\
Crude protein & 14.6 & 15.3 & 10.0 & $\left.46.4^{3}\right)$ & $\left.46.3^{3}\right)$ \\
Ether extract & 3.3 & 6.0 & 2.4 & - & - \\
Crude fibre & 8.9 & 33.0 & 35.7 & - & - \\
N-free extracts & 70.0 & 39.0 & 44.0 & - & - \\
kg DM/fu. & 0.98 & 1.30 & 2.0 & - & - \\
g DCP/fu. & 110 & 133 & 100 & - & - \\
\hline
\end{tabular}

f.u. (feed unit) $=0.7 \mathrm{~kg}$ starch

1) without urea, $1.0 \%$ of urea, $17.5 \% \mathrm{CP}, 2.8 \%$ of urea, $23.3 \% \mathrm{CP}$

${ }^{2}$ ) prewilted, ensiled with Viher solution (30\% acetic acid, $55 \%$ formalin) $51 / 1000 \mathrm{~kg}$ feed: pH 3.96, lactic acid $8.2 \%$, acetic acid $3.6 \%$, propionic acid $0.4 \%$ in $\mathrm{DM}, \mathrm{NH}_{3}-\mathrm{N} 7.0 \%$ of total nitrogen. 
Table 2. The ingredients of concentrate mixture in different periods.

\begin{tabular}{lcccc} 
& & \multicolumn{2}{c}{ Periods } & Tost-test \\
\cline { 3 - 4 } & Standardization & Group 1 & Group 2 & \\
\hline Barley & & 58 & 58 & 58 \\
Oats & 39 & 37 & 37 & 39 \\
Mineral mixture ${ }^{1}$ ) & 2 & 2.5 & 2.5 & 2 \\
Untreated urea & 1 & 2.5 & - & 1 \\
HCHO-treated urea & - & - & 2.5 & - \\
\hline
\end{tabular}

1) Containing, g/kg: Ca 165, P 85, Mg 30, Na 59, K 0.02, Mn 0.27, Zn 1.5, Fe 0.2, Cu 0.43, Se 50, Co 0.03.

the digestible crude protein requirement for milk production. The formaldehyde treatment was carried out by Kemira Ltd as described by SETÄLÄ and SYRJÄLÄ-QVIST (1982 a).

\section{Sampling and analyses}

The roughage was sampled every second week, in such a way that each sample represented the feed used during that period of the experiment. The concentrates were sampled each time when a new mixture was made. Analyses were made of each of the ingredients in the mixture.

Samples of feed refusals were taken every day, stored at $+4^{\circ} \mathrm{C}$ and analyzed at intervals of seven days. There was one sample per feed and cow for each seven-day period.

The amount of milk produced by each cow was weighed every week on two successive days. Milk samples for the analyses were taken every second week on the same days. The formaldehyde content of the milk was determined on samples taken once during the standardization period and four times during the test period.

The chemical analyses of the feeds and feed refusals of the cows were performed on samples pre-treated as described by SETÄLÄ and SYRJÄLÄQVIST (1982 c). The quality of the grass silage was determined as reported by SETÄLÄ et al. (1979). The volatile fatty acids (VFA) and their effect on the silage dry matter content were taken into account according to ULVESLI and BREIREM (1960). The formaldehyde content of the urea, silage and milk was determined by the method of BECK and GROSS (1973) with the modification of AOAC (ANON 1975, see also KREULA and RAURAMAA 1976).

The fat and protein contents of the milk were determined with the Milkoscan 300-analyzer.

\section{Calculations and statistical analyses}

The energy and digestible crude protein required for maintenance and milk production were calculated according to BREIREM (1969). The effect of change in the live weight of the cows was also taken into account.

The dry matter intake of the individual cows was calculated according to 
GREENHALG and McDONALD (1978). The intake of the feed given ad libitum was calculated by subtracting from the calculated total dry matter intake the consumption of individually fed concentrates and the consumption of the restricted feed. The intake of the restricted roughage was calculated as the average consumption of the group. Changes in the liveweight and their effects on the intake were taken into account as described by BREIREM (1969).

The ruminal degradation of the nitrogen in the feed and the fermentation of the feed organic matter were calculated for the concentrates, hay and silage from the results of SETÄLÄ and SYRJÄLÄ-QVIST (1982 d). The requirements for rumen degradable nitrogen $(\mathrm{RDN})$ and undegradable protein nitrogen (UDN) and for organic matter apparently fermented in the rumen were calculated according to ARC (ANON 1980) with the modification that metabolic faecal nitrogen was included, the value used being $2 \mathrm{~g}$ of metabolic faecal nitrogen $/ \mathrm{kg}$ DM intake (BURROUGHS et al. $1975 \mathrm{a}$ ). When the requirements for UDN were calculated the value chosen for microbial protein synthesis was 30 grams protein $\mathrm{N} / \mathrm{kg}$ organic matter apparently fermented in the rumen.

The differences in the degradation to ammonia of the treated and untreated urea were taken into account according to SETÄLÄ and SYRJÄLÄ-QVIST (1982 a). The theoretical utilization of urea as "urea fermentation potential" (UFP) was calculated by the method of BURROUGHS et al. (1975 b).

The yield data were tested by two-way analysis of covariance, where the regression variable was the yield of the preliminary period and the treatments were used as factors. Feed intake and nutrient consumption were tested by the analysis of variance and the differences between treatment means by the Tukey test (STEEL and TORRIE 1960).

\section{Results and discussion}

\section{Feed intake}

The average amounts of urea consumed by the cows receiving untreated urea and $\mathrm{HCHO}$-urea were respectively 121 and $133 \mathrm{~g} /$ day (Table 3 ). When the highest amount of urea, $220 \mathrm{~g} / \mathrm{cow} /$ day, was fed at the beginning of the test period, it decreased the palatability of the concentrates. The concentrates were consumed completely when the average daily amounts of urea given in the untreated urea and $\mathrm{HCHO}$-urea groups were $120(\max 130)$ and 130 (max. 160) grams of urea/cow, respectively.

\section{Milk yield and composition}

The cows receiving $\mathrm{HCHO}$-urea produced more $4 \%$ milk during the test period than the group given untreated urea but the difference was not statistically significant (Fig. 1). The difference was, however, significant $(\mathrm{P}<$ 0.01 ), when only the cows yielding more than $15 \mathrm{~kg}$ of $4 \% \mathrm{milk} /$ day were 
Table 3. The average daily intake of different feeds ( $\mathrm{kg} \mathrm{DM} /$ cow) during the test period (Group $1=$ untreated urea, Group 2 = HCHO-treated urea).

\begin{tabular}{cccccccc}
\hline & $\begin{array}{c}\text { Cows according } \\
\text { to } 4 \text { milk yield (kg/d) }\end{array}$ & $\begin{array}{c}\text { Number } \\
\text { of cows }\end{array}$ & $\begin{array}{c}\text { Grass } \\
\text { silage }\end{array}$ & Hay & $\begin{array}{c}\text { Concen- } \\
\text { trates }\end{array}$ & $\begin{array}{c}\text { Urea } \\
\text { Total DM } \\
\text { intake }\end{array}$ \\
\hline Group 1 & Whole group & 11 & 2.3 & 8.4 & 3.7 & 0.121 & 14.5 \\
& $>15$ & 5 & 2.3 & 8.7 & 3.9 & 0.127 & 15.0 \\
Group 2 & $<15$ & 6 & 2.3 & 8.0 & 3.6 & 0.119 & 14.0 \\
& Whole group & 11 & 2.3 & 8.9 & 4.1 & 0.133 & 15.4 \\
& $>15$ & 5 & 2.3 & 9.2 & 4.7 & 0.155 & 16.3 \\
& $<15$ & 6 & 2.3 & 8.6 & 3.6 & 0.119 & 14.6 \\
\hline
\end{tabular}

MILK YIELD, KG FCM/COW/DAY
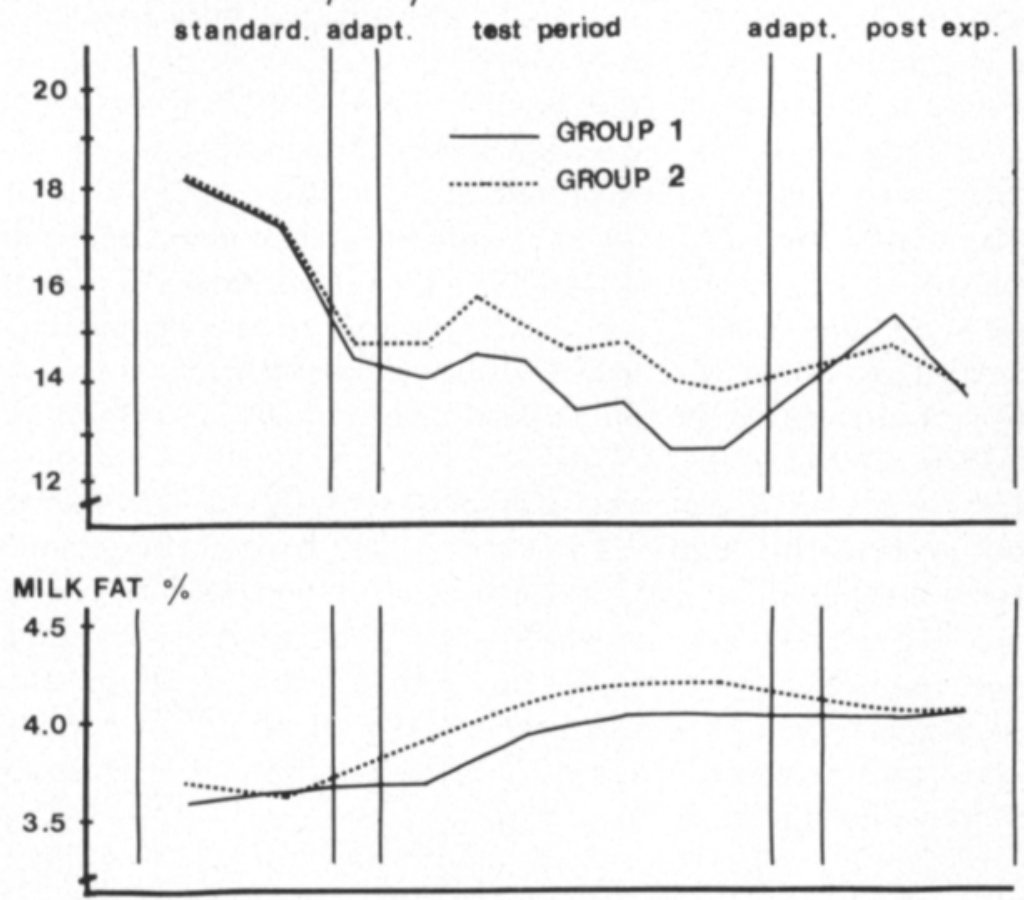

\section{MILK PROTEIN \%}

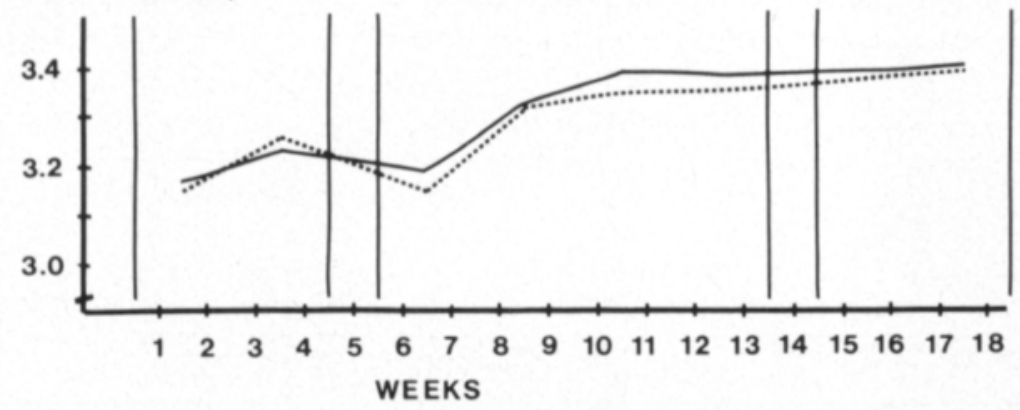

Figure 1. Milk yields and chemical composition of milk of different groups. (Group $1=$ untreated urea, Group 2 = HCHO-treated urea) 
considered (Table 4). The protein content of the milk did not differ significantly between the groups. Among the cows producing more than $15 \mathrm{~kg}$ of 4 $\%$ milk/day, the fat content was significantly lower in the $\mathrm{HCHO}$-urea group ( $\mathrm{P}<0.05$ ), but when the production level was below $15 \mathrm{~kg}$ of $4 \%$ milk, the fat content was significantly higher in this group $(P<0.05)$.

No significant differences were found in the utilization of energy or DCP for milk production (Table 4). The amounts of DCP used are higher than the suggested standards of BREIREM (1969).

The differences in the fat content of the milk are difficult to explain, because the roughage : concentrate ratio was the same in the rations of the two groups. It was also found in an earlier experiment of SETÄLÄ and SYRJÄLÄ-QVIST (1982 c) that the formaldehyde treatment tended to increase the proportion of acetic acid in the rumen VFA, which should not cause a lower fat content in the milk. One possible explanation is that in the $\mathrm{HCHO}-$ urea group the fat percent of the milk was affected by a greater energy shortage, suggested by LAIRD et al. (1981).

According to WOHLT and CLARK (1978) and WOHLT et al. (1978), urea was equal to soybean meal as a nitrogen source for cows producing $15-20 \mathrm{~kg}$ of FCM/day, provided the crude protein content of the total diet was about $12 \%$ of dry matter. In many papers the crude protein content of the diet has been suggested to be the critical factor for urea utilization. As is evident in the review by SETÄLÄ (1981), however, this factor can vary depending on the energy content and quality of the diet, and on the fermentation of energy and degradation of nitrogen in the rumen (MØLLER 1973, AITCHISON et al. 1976, MØLLER 1976, KWAN et al. 1977).

In grass silage-based diets the degradation of the protein of the total ration can be remarkably high (SETÄLÄ et al. 1982). In this experiment, where grass silage was replaced by hay, the calculated intakes of RDN without urea were lower than the requirements of the cows (Table 5). After the addition of urea, these requirements were met in both groups. Without urea, the calculated degradation of the nitrogen in the total rations of the urea and $\mathrm{HCHO}$-urea groups was $67 \%$ and $63 \%$, respectively, and with urea the corresponding values were $70 \%$ and $67 \%$.

Table 4. Milk yield (kg/d), milk composition, liveweight change, and utilization of energy (f.u.) and DCP per $\mathrm{kg}$ of $4 \%$ milk during the test period (Group 1 and 2, see Table 3).

\begin{tabular}{|c|c|c|c|c|c|c|c|c|c|c|c|}
\hline & \multirow{2}{*}{$\begin{array}{l}\text { Cows according } \\
\text { to } 4 \% \text { milk yield }\end{array}$} & \multirow{2}{*}{$\begin{array}{l}\text { Number } \\
\text { of cows }\end{array}$} & \multicolumn{2}{|c|}{$4 \%$ milk } & \multicolumn{2}{|c|}{ Fat $\%$} & \multicolumn{2}{|c|}{ Protein \% } & \multirow{2}{*}{$\frac{\text { f.u. }}{\text { per kg }}$} & \multirow{2}{*}{$\frac{\mathrm{g} \mathrm{DCP}}{\text { of } 4 \% \text { milk }}$} & \multirow{2}{*}{$\begin{array}{l}\text { Liveweight } \\
\text { change, } \mathrm{g} / \mathrm{d}\end{array}$} \\
\hline & & & $\overline{\mathbf{x}}$ & s.d. & $\hat{\mathbf{x}}$ & s.d. & $\hat{\mathbf{x}}$ & s.d. & & & \\
\hline \multirow[t]{3}{*}{ Group 1} & Whole group & 11 & $13.7^{2 \mathrm{C}}$ & 2.6 & $4.0^{4}$ & 0.25 & $3.3^{2}$ & 0.09 & $0.33^{2}$ & $63^{2}$ & $-107^{2}$ \\
\hline & $>15$ & 5 & $15.7^{\circ}$ & 0.9 & $4.2^{2}$ & 0.18 & $3.4^{a}$ & 0.10 & $0.32^{2}$ & $63^{2}$ & $-178^{2}$ \\
\hline & $<15$ & 6 & $12.0^{a \mathrm{C}}$ & 2.6 & $3.8^{2}$ & 0.16 & $3.3^{2}$ & 0.08 & $0.34^{2}$ & $63^{2}$ & $-53^{2}$ \\
\hline \multirow[t]{3}{*}{ Group 2} & Whole group & 11 & $14.6^{2 \mathrm{C}}$ & 2.7 & $4.1^{2}$ & 0.18 & $3.3^{2}$ & 0.09 & $0.36^{2}$ & $64^{2}$ & $-53^{2}$ \\
\hline & $>15$ & 5 & $17.7^{d}$ & 0.7 & $4.0^{b}$ & 0.14 & $3.3^{2}$ & 0.09 & $0.34^{2}$ & $61^{2}$ & $-214^{2}$ \\
\hline & $<15$ & 6 & $12.5^{\text {ac }}$ & 1.1 & $4.2^{\mathrm{b}}$ & 0.18 & $3.3^{2}$ & 0.10 & $0.37^{2}$ & $66^{2}$ & $+20^{a}$ \\
\hline
\end{tabular}

$a-b, P<0.05$, group means with different letters differ significantly

c-d, $P<0.01=$

f.u. (feed unit) $=0.7 \mathrm{~kg}$ starch 
Table 5. The requirements and intake of different nitrogen fractions as grams/cow/day in the total ration, and the utilization of urea as UFP (Group 1 and 2, see Table 3).

\begin{tabular}{|c|c|c|c|c|c|c|c|c|c|c|}
\hline & \multirow{2}{*}{$\begin{array}{c}\text { Cows according } \\
\text { to } 4 \% \text { milk yield }\end{array}$} & \multirow{2}{*}{$\begin{array}{l}\text { Number } \\
\text { of cows }\end{array}$} & \multicolumn{2}{|c|}{ RDN intake') } & \multirow{2}{*}{$\begin{array}{c}\text { RDN } \\
\text { required }\end{array}$} & \multirow{2}{*}{$\begin{array}{l}\text { UDN } \\
\text { intake') }^{2}\end{array}$} & \multirow{2}{*}{$\begin{array}{l}\text { UDN } \\
\text { required }\end{array}$} & \multicolumn{2}{|c|}{ Amino- $\mathrm{N}^{3}$} & \multirow{2}{*}{ UFP4 } \\
\hline & & & + Urea & - & & & & as Mbp & required & \\
\hline \multirow[t]{3}{*}{ Group 1} & Whole group & 11 & 249.4 & 194.1 & 235.8 & 83.2 & 26.7 & 188 & 223 & 93.1 \\
\hline & $>15$ & 5 & 258.6 & 200.6 & 243.9 & 86.1 & 47.0 & 195 & 242 & 96.0 \\
\hline & $<15$ & 6 & 242.5 & 188.5 & 228.0 & 79.8 & 13.7 & 182 & 196 & 88.0 \\
\hline \multirow[t]{3}{*}{ Group 2} & Whole group & 11 & 257.3 & 205.9 & 250.5 & 87.5 & 27.2 & 200 & 223 & 99.5 \\
\hline & $>15$ & 5 & 291.1 & 221.6 & 268.2 & 91.5 & 48.0 & 214 & 263 & 104.0 \\
\hline & $<$ & 6 & 239.7 & 193.7 & 224.4 & 84.1 & 14.3 & 189 & 204 & 95.1 \\
\hline
\end{tabular}

1) $\mathrm{RDN}=$ rumen degradable nitrogen

$\left.{ }^{2}\right)$ UDN = rumen undegradable protein nitrogen

3) Calculated according to ARC (ANON. 1980), Mbp = Microbial protein

4) UFP = Urea fermentation potential according to BURROUGHS et al. (1975 b)

The total intakes of RDN and UDN are higher than the suggested requirements. This can also be seen in the high amounts of DCP used per kilogram of $4 \%$ milk (see Table 4 ).

If the amino $\mathrm{N}$ available for the cow as microbial protein is calculated according to ARC (ANON 1980), microbial protein synthesis almost covered the requirements of the cows yielding less than $15 \mathrm{~kg}$ of $4 \% \mathrm{milk} /$ day. This is in agreement with the suggestion of VIRTANEN (1967).

The crude protein content of the ration DM was $14.5-14.8 \%$. The results of SETÄLÄ and SYRJÄLÄ-QVIST (1982 b) suggested that the utilization of the $\mathrm{HCHO}$-urea in microbial protein synthesis was better within this crude protein range than the utilization of the untreated urea. The higher methionine content in the bacterial mass (SETÄLÄ and SYRJÄLÄ-QVIST 1982 b) may have contributed to the higher milk yields of the $\mathrm{HCHO}$-urea group. Methionine, together with leucine, valine, phenylalanine and histidine, can be a limiting amino acid in the microbial protein used for milk production (VIRTANEN 1966, ARMSTRONG 1979, KAUFMANN 1979).

Table 6. Comparison of the $4 \%$ milk yields ( $\mathrm{kg} /$ cow/day) between the test period (b) and the standardization (a) and post-test (c) periods. (Group 1 and 2, see Table 3).

\begin{tabular}{|c|c|c|c|c|c|c|}
\hline & \multirow{3}{*}{$\begin{array}{l}\text { Cows according } \\
\text { to } 4 \% \text { milk yield }\end{array}$} & \multicolumn{4}{|c|}{ Periods } & \multirow{3}{*}{$\begin{array}{l}\text { Difference } \\
b-\frac{a+c}{2}\end{array}$} \\
\hline & & \multicolumn{2}{|c|}{ b } & \multirow{2}{*}{\multicolumn{2}{|c|}{$\begin{array}{c}\frac{a+c}{2} \\
\frac{2 . d .}{\text { s.d. }}\end{array}$}} & \\
\hline & & $\bar{x}$ & s.d. & & & \\
\hline \multirow[t]{3}{*}{ Group 1} & Whole group & 13.7 & 2.6 & 16.7 & 2.6 & $-3.0^{*}$ \\
\hline & $>15$ & 15.7 & 0.9 & 17.9 & 1.1 & $-2.2^{4}$ \\
\hline & $<15$ & 12.0 & 2.6 & 14.8 & 3.4 & -2.8 \\
\hline \multirow[t]{3}{*}{ Group 2} & Whole group & 14.6 & 2.7 & 15.5 & 3.4 & -1.1 \\
\hline & $>15$ & 17.7 & 0.7 & 17.8 & 3.5 & -0.1 \\
\hline & $<15$ & 12.5 & 1.1 & 13.1 & 0.6 & -0.6 \\
\hline
\end{tabular}

- $\mathrm{P}<0.05$ 
When the milk yields of the test period were compared with those of the standardization and post-test periods, the milk yield of the untreated urea group was found to be significantly $(\mathrm{P}<0.05)$ lower in the test period. Calculated as DCP according to Lampila (1968), urea covered on average about $25 \%$ of the DCP required for milk production in both groups. It has been found that milk production may be decreased when urea contributes about $30 \%$ of the DCP needed for milk production and the daily milk yields are more than $12-14 \mathrm{~kg}$ of $4 \%$ milk/cow (LAMPILA 1968, POUTIAINEN 1970, ETTALA et al. 1977). MØLLER and NEIMANN-SØRENSEN (1977) suggested that urea $\mathrm{N}$ could contribute 18 and $31 \%$ of total $\mathrm{N}$ without a decrease in milk production when the daily yields are respectively less than 19.7 and $16.6 \mathrm{~kg}$ of $\mathrm{FCM} / \mathrm{cow}$.

\section{Formaldehyde in milk}

Formaldehyde was found in only five of the 55 milk samples and those samples were taken in the $\mathrm{HCHO}$-urea group during the test period (see also SYRJÄLÄ-QVIST and SETÄLÄ 1982 a, b). The amount of formaldehyde consumed in the feeds did not show any clear relation with the formaldehyde content of the milk. The cows received about 1.79-2.39 g of formaldehyde/ day, and the formaldehyde content of the milk varied from 0.2 to $0.3 \mathrm{mg}$ of formaldehyde/ $\mathrm{kg}$ milk. The amounts of formaldehyde found in the milk were lower than in the experiment of KREULA and RAURAMAA (1976) and BECK and GROSS (1973), but the intakes of formaldehyde were also lower. The comsumption of formaldehyde was also below the limit suggested by KAEMMERER and KERBER (1977) for the transfer of formaldehyde to milk.

In conclusion, formaldehyde-treated urea can be used successfully in feeding of lactating dairy cows. The results of this experiment suggest that its substitution for untreated urea may have a beneficial effect on milk production.

Acknowledgements. The authors wish to express their gratitude to Kemira Ltd. for the preparation of urea and to Kemira Foundation for financial support during the experiment. They are indebted to the Valio laboratories for the milk analyses and the determination of formaldehyde in the feeds and milk. They are also most grateful to Jorma Tossavainen and Margareta Malen for their excellent care of the experimental animals.

\section{References}

AITCHISON, T, E., MERTENS, D. R., McGIlliARD, A. D. \& JACOBSON, N. L. 1976. Effect of nitrogen solubility on nitrogen utilization in lactating dairy cattle. J. Dairy Sci. 59: 2056-2062.

ANON. 1975. Association of Official Agricultural Chemists, Official Methods of Analysis. 12th ed., Washington. $1015 \mathrm{p}$.

ANON. 1980. The nutrient requirements of ruminant livestock, Commonwealth Agricultural Bureaux. $351 \mathrm{p}$.

ARMSTRONG, D. G. 1979. Factors affecting amino acid supply to the ruminant - the significance of protein quality in ruminants. Protein utilization in farm animals II. Internordic licentiat/doctorand course, Tune, Denmark. 24 p. 
BECK, Th. \& GROSS, F. 1973. Zur Frage der Rückstande bei der Verwerdung Formaldehydhaltiger Zusatzmittel bei der Gärfutterbereitung. Das Wirtschaftseigene Futter 19: 282-289.

BREIREM, K. 1969. Fornormer. K. K. Heje/Singsaas Lommealmanakk 1: 120. Oslo.

BURROUGHS, W., NELSON, D. K. \& MARTENS. D. R. 1975 a. Protein physiology and its application in lactating cow: the metabolizable protein feeding standard. J. Anim. Sci. 41: 933-944.

— , NELSON, D. K. \& MARTENS, D. R. 1975 b. Evaluation of protein nutrition by metabolizable protein and urea fermentation potential. J. Dairy Sci. 58: 611-619.

ETTALA, E., MIKKONEN, H. \& LAMPILA, M. 1977. Urea valkuaisen osittaisena korvaajana tuotantokauden keskivaiheessa. Kehittyvä Maatalous 34: 16-23.

GREENHALG, J. F. D. \& McDONALD, I. 1978. The metabolizable energy system in practice: Predicting feed intake. Anim. Prod. 26: 350.

KAEMMERER, K. \& KERBER, H-J. 1977. Formaldehydgeschütztes Sojaprotein in Verträglichkeitsversuch bei Ratten. DLG-Forschungsberichte über Tierern. 538004: 2-44.

KAUFMANN, W. 1979. Protein utilization. EAAP-publ. 23: 90-113.

KREULA, M. \& RAURAMAA, A. 1976. Transfer of formaldehyde from feed to milk during the feeding of fresh cut grass treated with formaldehyde-containing preservative. J. Scient. Agric. Soc. Finl. 48: 154-157.

KWAN, K., COPPOCK, C. E., LAKE, G. B., FETTMAN, M. J., CHASE, L. E. \& McDOWELL, R. E. 1977. Use of urea by early postpartum Holstein cows. J. Dairy Sci. 60: 1706-1724.

LAIRD, R., LEAVER, J. D. \& MOISEY, F. R. 1981. The effects of concentrate supplements on the performance of dairy cows offered grass silage ad libitum. Anim. Prod. 33: 199-209.

LAMPILA, M. 1968. Urea supplements in the rations of dairy cows. Ann. Agric. Fenn. 7: 46-58.

MØLLER, P. D. 1973. The influence of different carbohydrate sources on the utilization of urea nitrogen by lactating cows. 412. Beretn. Landøkon. Forsogslab. 204 p.

- 1976. Zur Bedeutung der Harnstoff-Fütterung an Milchkühe. Kraftfutter 59, 5: 174-180.

- \& NEIMANN-SØRENSEN, A. 1977. Economic and other considerations governing decisions on the advisability of incorporating additional and new sources of protein and non-protein nitrogen into the diets of dairy cattle - the case of urea-nitrogen for lactating dairy cows. Protein and nonprotein nitrogen for ruminants. p. 33-50. Pergamon Press.

POUTIAINEN, E. K. 1970. The partial substitution of protein by urea in rations for dairy cows. Ann. Agric. Fenn. 9: 142-150.

— 1981. Formaldehydi-urean hyväksikäyttö märehtijällä. Lic. thesis, University of Helsinki. 95 p.

SETÄLÄ, J., SEPPÄLÄ, J., PIRINEN, S., POUTIAINEN, E. \& PULLI, S. 1979. Maize for silage I. Conservation of whole maize plant for silage with treatment of preservatives and urea before ensiling. J. Scient. Agric. Soc. Finl. 51: 229-237.

— \& SYRJÄLÄ-QVIST, L. 1982 a. The degradation and utilization of formaldehyde-treated urea by rumen microbes in vitro. J. Scient. Agric. Soc. Finl. 54: 15-24.

— \& SYRJÄLÄ-QVIST, L. 1982 b. Effect of the crude protein level on the utilization of untreated and formaldehyde-treated urea in vitro. J. Scient. Agric. Soc. Finl. 54: 25-31.

— \& SYRJÄLÄ-QVIST, L. 1982 c. Effect of formaldehyde-treated urea on rumen fermentation, ration digestibility and nitrogen utilization. J. Scient. Agric. Soc. Finl. 54: 33-42.

— \& SYRJÄLÄ-QVIST, L. 1982 d. The ruminal degradation of protein in feeds generally used in Finland. To be published.

— \& SYRJÄLÄ-QVIST, L., POUTIAINEN, E. K. \& TUORI, M. 1982. (unpublished).

STEEL, R. G. \& TORRIE, J. H. 1960. Principles and procedures of statistics. New York. 481 p.

SYRJÄLÄ-QVIST, L. \& SETÄLÄ, J. 1982 a. Formaldehyde content of milk 1. Cows fed on protein concentrates treated with different amounts of formaldehyde. J. Scient. Agric. Soc. Finl. 54: 0.

- SETÄLÄ, J. 1982 b. Formaldehyde content of milk 2. Cows fed on grass silage preserved with formaldehyde-containing additive and on formaldehyde-treated urea. J. Scient. Agric. Soc. Finl. 54: 63-67.

ULVESLI, O. \& BREIREM, K. 1960. Forsøk over ensileringsmetoder. Meld. Norg. Landbr. høgsk. 39, 16: 1-75.

VIRTANEN, A. I. 1966. Milk production of cows on protein-free feed. Science 153: 1603-1614.

- 1967. The production of milk on protein-free rations. Urea as a protein supplement, ed. Briggs, M. H. p. 185-212. Pergamon Press.

WOHLT, J. E. \& Clark, J. H. 1978. Nutritional value of urea versus preformed protein for ruminants I. Lactation of dairy cows fed corn based diets containing supplemental nitrogen from urea and/or soybean meal. J. Dairy Sci. 61: 902-915. 
— , CLARK, J. H. \& BLAISDELL, F. S. 1978. Nutritional value of urea versus preformed protein for ruminants II. Nitrogen utilization by dairy cows fed corn based diets containing supplemental nitrogen from urea and/or soybean meal. J. Dairy Sci. 61: 916-931.

Ms received April 13, 1982

\title{
SELOSTUS
}

\section{Käsittelemätön ja formaldehydillä käsitelty urea lypsylehmien typen- lähteenä}

\author{
Jouko Setälä ja Liisa Syrjälä-Qvist
}

Helsingin yliopisto, kotieläintieteen laitos

00710 Helsinki 71

Tutkimuksessa verrattiin käsittelemätöntä ja 1.5 prosentilla formaldehydiä käsiteltyä ureaa lypsylehmien ruokinnassa, kun urealla korvattiin noin 25-30 prosenttia maidontuotannon srv-tarpeesta. Kokeessa oli 22 fr-rotuista lehmää ja koe suoritettiin ryhmäjaksokokeena, jossa siirtojaksojen pituus oli yksi viikko. Vakiointijaksolla (4 vk) ja jälkijaksolla (4 vk) lehmät saivat esikuivattua nurmisäilörehua vapaasti. Vertailujaksolla (8 vk) nurmisäilörehun määrää rajoitettiin ja kuivaa heinää annettiin vapaasti. Viljaseosta annettiin 0.3 kiloa/4 \%-maitokilo/lehmä kaikilla jaksoilla. Väkirehussa oli vakiointi- ja jälkijaksolla käsittelemätöntä ureaa yksi prosentti ja vertailujaksolla käsittelemätöntä tai käsiteltyä ureaa 2.5 prosenttia. Väkirehuruokinta oli yksilökohtainen ja karkearehuruokinta ryhmäkohtainen.

Kokeessa formaldehydi-ureaa saaneet lehmät tuottivat enemmän 4-\%:ista maitoa/lehmä/d ja ero oli merkitsevä $(\mathrm{P}<0.01)$ lehmäryhmissä, joissa keskituotos oli yli 15 kiloa 4-\% :ista maitoa päivässä. Tässä ryhmässä formaldehydi-urea -ruokinnalla olleiden lehmien maidon rasvapitoisuus oli merkitsevästi $(\mathrm{P}<$ $0.05)$ alhaisempi, mutta alle 15 kiloa lypsävien lehmien ryhmässä taas korkeampi $(\mathrm{P}<0.05)$ käsittelemätöntä ureaa saaneeseen ryhmään verrattuna. Maidon valkuaispitoisuudessa ei ollut merkitsevää eroa ryhmien välillä.

Formaldehydi-urea -ryhmässä todettiin formaldehydiä viidessä maitonäytteessä, joissa pitoisuudet olivat $0.2-0.3 \mathrm{mg}$ formaldehydiä/maito-kg. Formaldehydin saanti ei kuitenkaaan vaikuttanut selvästi maidon formaldehydi-pitoisuuteen. 